Vol. 5 No. 1 (Januari 2022), Halaman: $75-84$

Available Online at http://ejurnal.ubharajaya.ac.id/index.php/Jabdimas

\title{
Pemanfaatan Media Pembelajaran Audio Visual Berbasis Aplikasi Canva
}

\author{
Ari Nurul Alfian ${ }^{1}$, Mardi Yudhi Putra ${ }^{1}$, Rita Wahyuni Arifin ${ }^{1,}$, , Agung Barokah ${ }^{1}$, Ahmad \\ Safei ${ }^{1}$, Novan Julian ${ }^{1}$ \\ ${ }^{1}$ Fakultas Informatika; Universitas Bina Insani; Jl.Siliwangi no.6 Rawa panjang, telp/fax: 021 - \\ 82436886 / 021-824 36 996; e-mail: arin@binainsani.ac.id, mardi@binainsani.ac.id, \\ ritawahyuni@binainsani.ac.id, agungbarokah117@gmail.com, gilangmuktisetio123@gmail.com, \\ novanjulian07@gmail.com \\ * Korespondensi: e-mail: ritawahyuni@binainsani.ac.id,
}

Submitted: 07/01/2022; Revised: 13/01/2022; Accepted: 21/01/2022; Published: 31/01/2022

\begin{abstract}
The ability to master technology and information, especially learning media for educators in mastering the concept of learning media is very necessary. The problems faced by educators from HIMPAUDI are still not utilizing learning media in the learning process. In addition, they still don't understand how to make learning media using the Canva application. The solution to the problems above is to create learning media and learning videos using Canva. The method in implementing this Community Service activity with the main target being educators at HIMPAUDI, West Bekasi District where there are 2 resource persons, 2 moderators and 2 technical support people. PkM was held on Saturday, December 22, 2021. PkM was conducted by providing training and demonstrations to participants in using Canva applications with the support of online media in the form of zoom, YouTube and Google Drive links. The outputs of this PkM are YouTube Streaming and a draft of the BRIN Sinta Ristek Indexed PkM Journal.
\end{abstract}

Keywords: Audio Visual, Canva, Learning Media, PkM

\begin{abstract}
Abstrak
Kemampuan penguasaaan teknologi dan informasi khususnya media pembelajaran pada para Pendidik dalam penguasaan konsep media pembelajaran sangat diperlukan. Persoalan yang dihadapi para pendidik dari HIMPAUDI masih belum memanfaatkan media pembelajaran dalam proses pembelajaran. Selain itu, masih belum memahami pembuatan media pembelajaran menggunakan aplikasi canva. Solusi dari permasalahan di atas adalah membuat media pembelajaran serta video pembelajaran menggunakan Canva. Metode dalam pelaksanaan kegiatan Pengabdian kepada Masyarakat ini dengan sasaran utama adalah para Pendidik pada HIMPAUDI Kecamatan Bekasi Barat dimana terdapat 2 orang Narasumber, 2 orang Moderator dan 2 orang Techinal Support. PkM dilaksanakan pada hari Sabtu, 22 Desember 2021. PkM dilakukan dengan memberikan pelatihan dan demonstrasi kepada peserta dalam penggunaan aplikasi dari Canva dengan dukungan media online berupa zoom, YouTube dan Link Google Drive. Luaran dari PkM ini adalah Streaming YouTube dan draft Jurnal PkM Terindeks Sinta Ristek BRIN.
\end{abstract}

Kata kunci: Audio Visual, Canva, Media Pembelajaran, PkM

\section{Pendahuluan}

PAUD (Pendidikan Anak Usia Dini) merupakan jenjang pendidikan sebelum jenjang pendidikan dasar yang merupakan suatu upaya pembinaan yang ditujukan bagi anak sejak lahir 
sampai dengan usia enam tahun yang dilakukan melalui pemberian rang sangan pendidikan untuk membantu pertumbuhan dan perkembangan jasmani dan rohani agar anak memiliki kesiapan dalam memasuki pendidikan lebih lanjut, yang diselenggarakan pada jalur formal, nonformal, dan informal. Lebih lanjut, PAUD merupakan salah satu bentuk penyelenggaraan pendidikan yang menitikberatkan pada peletakan dasar ke arah pertumbuhan dan perkembangan fisik (koordinasi motorik halus dan kasar), kecerdasan (daya pikir, daya cipta, kecerdasan emosi, kecerdasan spiritual), sosio emosional (sikap dan perilaku serta agama) bahasa dan komunikasi, sesuai dengan keunikan dan tahap-tahap perkembangan yang dilalui oleh anak usia dini (J. Tedjawati, 2011).

HIMPAUDI adalah suatu organisasi independen yang menghimpun unsur pendidik dan tenaga kependidikan anak usia dini. Pendidik anak usia dini adalah tenaga yang berperan men jadi panutan, pembimbing, pengasuh dan fasilitator bagi anak usia dini. Pendidik bagi anak usia dini disebut pendidik (guru). Sedangkan tenaga kependidikan adalah pengelola, pemerhati, pakar, praktisi dan masyarakat umum lainnya yang melaksanakan program PAUD (J. M. Tedjawati, 2011).

Peningkatan kinerja pendidikan pada masa mendatang diperlukannya sistem informasi dan teknologi informasi yang mana tidak hanya berfungsi sebagai sarana pendukung, tetapi sebagai senjata utama untuk mendukung keberhasilan dunia pendidikan sehingga mampu bersaing dalam dunia global (Budiman, 2017).

Salah satu dari banyaknya aplikasi yang telah hadir dalam dunia teknologi ialah Canva. Canva adalah program desain online yang menyediakan bermacam peralatan seperti presentasi, resume, poster, pamflet, brosur, grafik, infografis, spanduk, penanda buku, bulletin, dan lain sebagainya yang disediakan dalam aplikasi canva. Adapun jenis-jenis presentasi yang ada pada Canva seperti presentasi kreatif, pendidikan, bisnis, periklanan, teknologi, dan lain sebagainya (Pelangi et al., 2020).

Adapun permasalahan pada mitra, yaitu: pada tenaga pendidik dari HIMPAUDI untuk saat ini belum ada pemanfaatan media pembelajaran berbasis teknologi informasi dalam mendukung kegiatan pembelajaran, sehingga para tenaga pendidik ingin mengetahui mengenai pemanfaatan media pembelajaran audio visual menggunakan aplikasi Canva.

Penggunaan media audio visual mampu menarik perhatian siswa dalam belajar dan dapat memberikan motivasi belajar dan kemudahan kepada siswa untuk memahami materi yang disampaikan guru, dengan cara guru menampilkan video motivasi dan video pembelajaran yang, serta melalui penyajian microsoftpowerpoint yang berkaitan dengan materi yang dibahas (Magdalena \& Astikawati, 2018).

Upaya guru dalam mempermudah penyampaian informasi dalam pembelajaran perlu adanya media pembelajaran yang menarik bagi peserta didik. Pembelajaran yang dikelola memperhatikan aspek perkembangan IImu pengetahuan teknologi (Adittia, 2017). 
Canva adalah aplikasi yang dapat digunakan untuk melakukan desain grafis . Penggunaan aplikasi Canva dapat meningkatkan kreativitas dalam membuat desain poster, presentasi, dan konten visual lainnya (Sholeh et al., 2020). Tujuan penelitian ini adalah untuk mengembangkan media pembelajaran audio visual berbasis aplikasi canva. Tujuan kegiatan PkM ini agar dapat mengembangkan media pembelajaran audio visual berbasis aplikasi canva (Rahmatullah et al., 2020). Salah media pembelajaran daring adalah Aplikasi Canva yaitu program desain online yang menyediakan bermacam peralatan seperti presentasi, resume, poster, pamflet, brosur, grafik, infografis, spanduk, penanda buku, bulletin, dan lainnya (Sony Junaedi, 2021).

Solusi dari permasalahan Mitra PkM adalah: diadakannya webinar PkM dengan tema media pembelajaran yang berjudul pemanfaatan media pemebelajaran audio visual berbasis aplikasi canva sehingga saat bekerja nanti dapat mengimplementasikan ilmu pengetahuan mengenai media pembelajaran. Luaran dari PkM ini adalah Jurnal PkM Terindeks Sinta Ristek BRIN dan video youtube.

Berlandaskan program HIMPAUDI serta pentingnya informasi dan teknologi informasi yang berfungsi sebagai sarana pendukung dan memperkaya pengetahuan Guru dan anak maka PkM ini diajukan sebagai salah satu wadah dalam memperdalam pengetahuan Guru PAUD pada bidang Pendidikan.

Melalui Bantuan Pendanaan Program Penelitian Kebijakan Merdeka Belajar Kampus Merdeka Dan Pengabdian Kepada Masyarakat Berbasis Hasil Penelitian Perguruan Tinggi Swasta Tahun 2021, Universitas melakukan pengabdian kepada Masyarakat pada tingkat Perguruan Tinggi dengan Judul "Pemanfaatan Media Pembelajaran Audio Visual Berbasis Aplikasi Canva". PkM ini dilakukan sebagai bentuk implementasi program Merdeka Belajar Kampus Merdeka (MBKM).

\section{Metode Pelaksanaan}

Adapun tahapan kegiatan pengabdian ini adalah analisa permasalahan masyarakat, identifikasi masalah dan pencarian solusi permasalahan, pelaksanaan kegiatan, evaluasi kegiatan dan hasil (Fitria et al., 2021).

Metode pelaksanaan yang ditetapkan untuk mencapai kegiatan pengabdian melalui Bantuan Pendanaan Program Penelitian Kebijakan Merdeka Belajar Kampus Merdeka Dan Pengabdian Kepada Masyarakat Berbasis Hasil Penelitian Perguruan Tinggi Swasta Tahun 2021 yaitu 1) Pengabdian kepada Masyarakat (PkM) dampak MBKM dilakukan di Program Studi lalu dilanjutkan pelaksanannya pada tingkat fakultas dan pada sesi berikutnya dilanjutkan pada tingkat perguruan tinggi. 2) Melibatkan seluruh pimpinan perguruan tinggi, pimpinan fakultas, pimpinan program studi, seluruh dosen dan seluruh mahasiswa di perguruan tinggi tersebut. 3) PkM dilakukan pada minggu ke-1 s.d 3 Bulan Desember, pelaksanaan PkM mengadopsi Software Audio Visual Canva. 4) Sebelum kegiatan pelaksanaan kegiatan PkM dilakukan terlebih 
dahulu dilaksanakan diskusi kecil diantara pimpinan HIMPAUDI, perwakilan guru PAUD, dosen, dan juga mahasiswa. 5) Hasil Pengabdian kepada Masyarakat (PkM) akan dilakukan seminar pada tingkat prodi, fakultas dan perguruan tinggi. 6) Pelaksanaan Kegiatan PkM dilaksanakan pada tanggal 22 Desember 2021 di ruang seminar lantai 2 Universitas Bina Insani dan dihadiri sebanyak 20 peserta yang terdiri dari pendidik dan tenaga pendidik dari PAUD yang tergabung dalam himpunan organisasi HIMPAUDI.

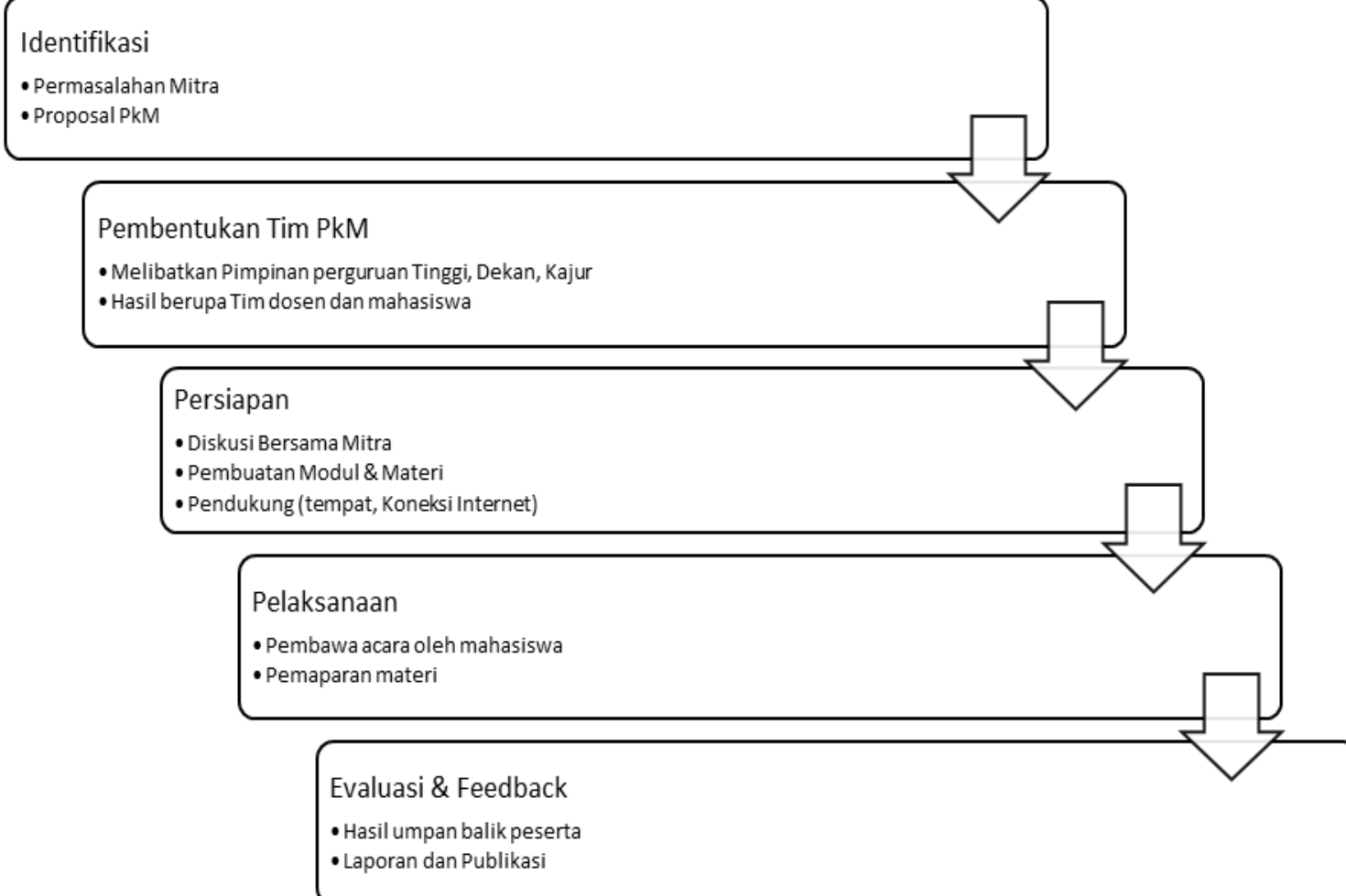

Sumber: Hasil Pelaksanaan (2021)

\section{Gambar 1. Langkah - langkah Pelaksanaan PkM}

Pada gambar 1 menjelaskan tentang langkah-langkah yang dilakukan untuk kegiatan pelaksanaan Pengabdian kepada Masyarakat pada HIMPAUDI Mustika Jaya kota Bekasi. Kegiatan dimulai dari melakukan identifikasi, artinya mengidentifikasi persoalan yang dihadapi mitra, dan apa saja yang menjadi kebutuhan sehingga dapat dengan mudah untuk dilakukan pemetaan solusi terhadap permasalahan tersebut. Pada tahap selanjutnya Pembentukan Tim, artinya melibatkan seluruh stakeholder terkait dengan pelaksanaan PkM seperti Pimpinan perguruan tinggi, Dekan Fakultas dan Ketua jurusan serta dosen. Sehingga memberikan hasil berupa Tim dosen dan mahasiswa yang akan dilibatkan pada kegiatan PkM. Tahap berikutnya yaitu pelaksanaan, artinya dumulai pembukaan oleh Ketua HIMPAUDI, Ketua LPPM Universitas Bina Insani yang dibawakan oleh pembawa acara yakni mahasiswa yang terlibat, kemudian dilanjutkan dengan pemaparan materi serta praktek langsung terkait media pembelajaran audio visual oleh narasumber. Diakhir tahapan evaluasi dan feedeback, artinya kegiatan diberikan umpan balik terkait kegiatan sehingga dapat mengukur kemampuan peserta terhadap 
penggunaan aplikasi audio visual. Kemudian tim PkM membuat laporan akhir beserta membuat artikel yang dipublikasi pada jurnal nasional sebagai betuk dari luaran kegiatan PkM.

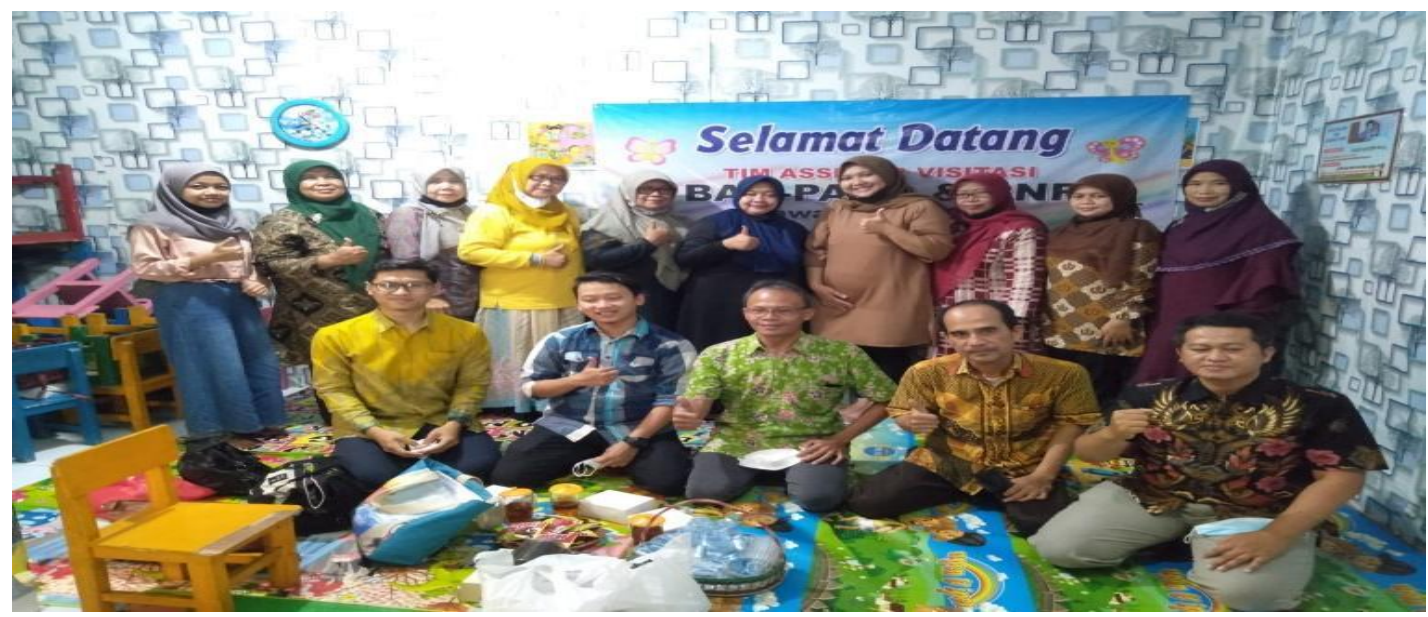

Sumber: Hasil Pelaksanaan (2021)

Gambar 2. Diskusi kecil sebelum pelaksanaan

Pada gambar 2 menjelaskan tentang pelaksanaan diskusi kecil yang terdiri dari tim PkM beserta guru HIMPAUDI sebelum pelaksanaan kegiatan Pengabdian kepada Masyarakat. Kegiatan diskusi menghasilkan permasalahan yang dihadapi mitra, solusi terhadap usulan permasalahan serta waktu dan tempat pelaksanaan kegiatan PkM.
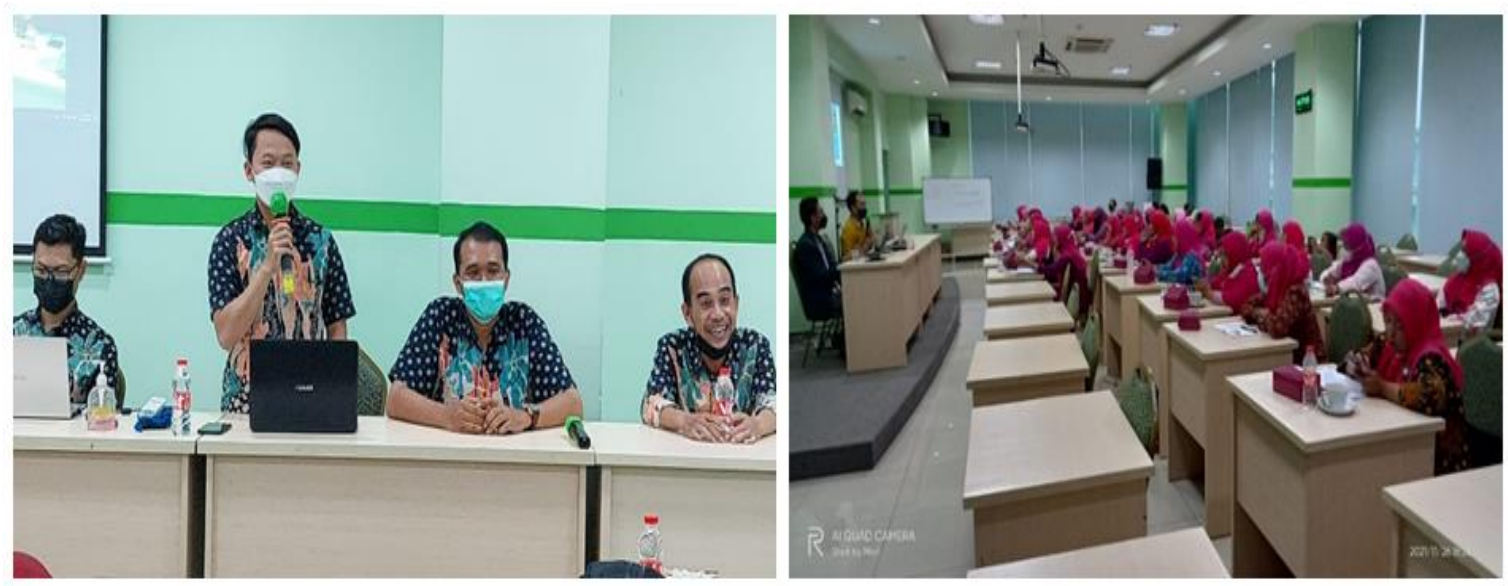

Sumber: Hasil Pelaksanaan (2021)

Gambar 3. Kegiatan Pelaksanaan PkM

Pada gambar 3 menjelaskan tentang kegiatan pelaksanaan PkM yang dilaksanakan pada ruang seminar lantai 2 Universitas Bina Insani Bekasi. Peserta yang mengikuti kegiatan PkM penuh dengan semangat dalam memahami materi yang disampaikan narasumber. Kegiatan dimulai dari sambutan ketua LPPM kemudian sambutan ketua HIMPAUDI Mustika Jaya Kota Bekasi. Selanjutnya pemaparan oleh narasumber terkait materi pemanfaatan aplikasi canva pada media pembelajaran. Pada sesi akhir kegiatan dilakukan diskusi dan tanya jawab seputar materi dan pemberian umpan balik terkait materi dan kegiatan yang dilakukan kepada peserta melalui google form. 


\section{Hasil dan Pembahasan}

Berdasarkan hasil dari kegiatan PkM selesai mengikuti pelatihan ini diharapkan seluruh peserta dapat memahami Pemanfaatan Media Pembelajaran Audio Visual Berbasis Aplikasi Canva. Kegiatan ini juga sebagai target capaian dari implementasi kerjasama Universitas Bina Insani dengan HIMPAUDI. Wujud dari target pencapaian kegiatan PkM dapat dilihat melalui jumlah peserta pendaftar 24 (dua puluh emapat) pendaftar pada link pendaftaran https://bit.ly/absensipkmgasal2122himpaudi dan respon feedback dari peserta setelah mengikuti kegiatan PkM yang diberikan melalui link google form https://bit.ly/angketpkmgasal2122himpaudi ada sebanyak 17 (tujuh belas) responses.

Peserta yang terdaftar berasal dari berbagai Himpaudi kecamatan mustika jaya. Berikut ini pada gambar 4 ditunjukkan jumlah peserta berdasarkan asal HIMPAUDI yang mengikuti kegiatan PkM.

\section{Asal PAUD}

24 responses

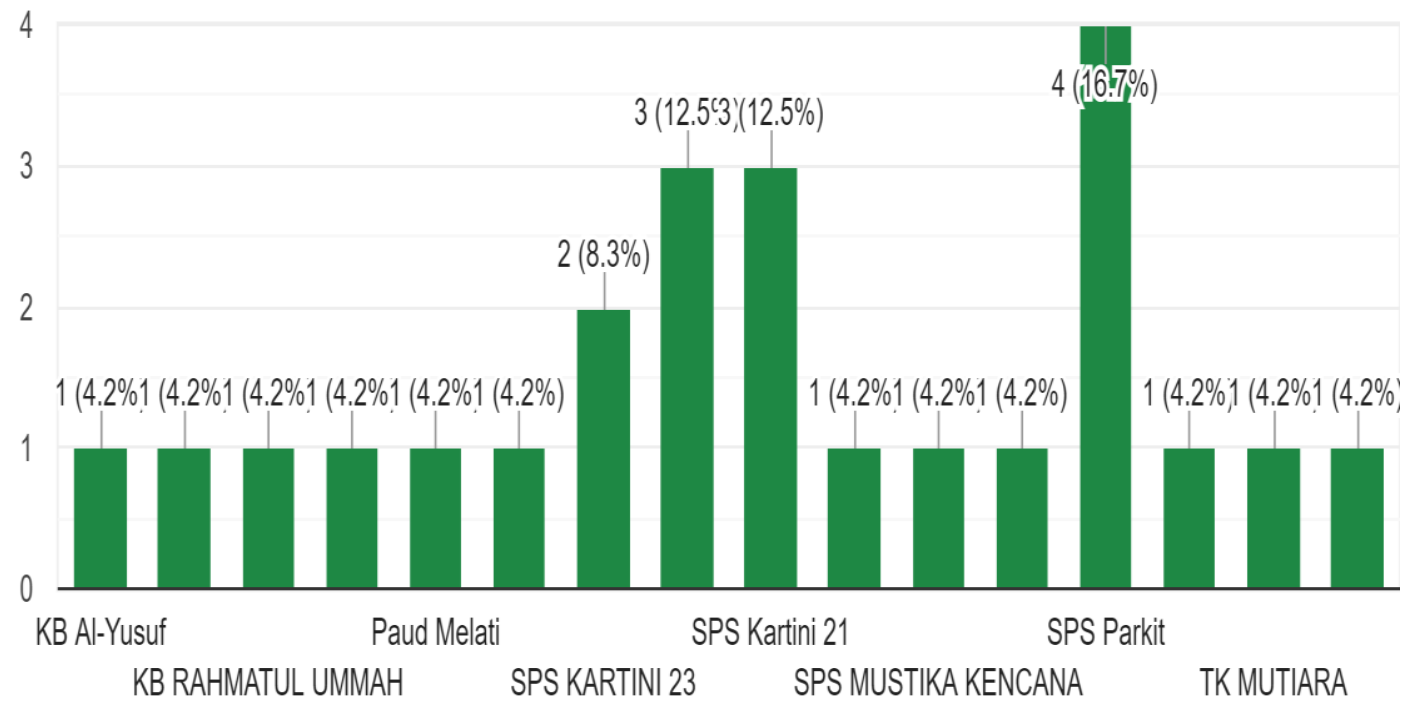

Sumber: Hasil Pelaksanaan (2021)

Gambar 4. Peserta HIMPAUDI

Evaluasi terhadap pelaksanaan kegiatan berupa feedback terdiri 10 pertanyaan, dengan penilaian menggunakan skala Likert dari penilaian sangat positif sampai dengan sangat negatif, berupa pemilihan kata dan diberi skor (Suryana et al., 2013).

Kisaran nilai: Baik Sekali=5, Baik=4, Cukup=3, Kurang=2, Sangat kurang=1. Kemudian dari hasil kuesioner dilakukan perhitungan menggunakan rumus sehingga dapat diukur hasil kegiatan PkM yang diperoleh dari skor jawaban responden (Kusuma et al., 2016). 
Prosentase Kelayakan $(\%)=\frac{\text { Skor yang diobservasi }}{(\text { Skor } y a n g \text { diharapkan })} \times 100 \%$

Prosentase Kelayakan $(\%)=\frac{\text { skor yang diobservasi }}{(\text { Skor yang diharapkan })} \times 100 \%$

Dalam kegiatan PkM kuesioner diberikan sesaat setelah pembicara menyampaikan materinya, hal tersebut dilakukan untuk mengetahui respon peserta terhadap materi yang diberikan dan keseluruhan pelaksanaan webinar, dalam kuesioner tersebut terdiri dari 10 pertanyaan yang disebar melalui google form yaitu sebagai berikut: a) materi yang dibawakan oleh pembicara; b) respon terhadap materi; c) kesesuaian materi dengan kebutuhan peserta; d) kaitan antara materi dan aplikasi yang diserap peserta; e) kaitan antara materi dan kebutuhan; f) teknik penyajian materi; g) kesesuain waktu dengan materi yang diberikan; $\mathbf{h}$ ) materi yang dijelaskan oleh narasumber; i) ketertarikan peserta terhadap kegiatan; j) kepuasan peserta terhadap kegiatan secara keseluruhan.

Adapun rekap mengenai hasil perhitungan feedback ditampilkan pada tabel 1 sebagai berikut:

Tabel 1. Rekap Perhitungan Feedback

\begin{tabular}{cccccc} 
Pertanyaan & Baik Sekali & Baik & Cukup & Kurang & Sangat Kurang \\
\hline $\mathbf{1}$ & 82 & 12 & 6 & 0 & 0 \\
\hline $\mathbf{2}$ & 94 & 6 & 0 & 0 & 0 \\
\hline $\mathbf{3}$ & 47 & 47 & 6 & 0 & 0 \\
\hline $\mathbf{4}$ & 59 & 29 & 12 & 0 & 0 \\
\hline $\mathbf{5}$ & 41 & 18 & 12 & 0 & 0 \\
\hline $\mathbf{6}$ & 47 & 35 & 18 & 0 & 0 \\
\hline $\mathbf{7}$ & 41 & 35 & 24 & 0 & 0 \\
\hline $\mathbf{8}$ & 59 & 35 & 4 & 0 & 0 \\
\hline $\mathbf{9}$ & 53 & 41 & 0 & 0 & 0 \\
\hline $\mathbf{1 0}$ & 41 & 41 & 18 & 0 & 0
\end{tabular}

Sumber: Hasil Pelaksanaan (2021)

Tabel 1 menjelaskan tentang rekap hasil feedback yang disajikan dalam bentuk grafik, dan dari data diatas dapat disimpulkan bahwa rata-rata respon peserta memberikan nilai 5 atau baik sekali. Sedangkan untuk hasil prosentase kelayakan dari tiap pertanyaan yang diberikan dalam feedback dilakukan perhitungan dengan rumus:

Prosentase Kelayakan (\%) $=\frac{\text { Skor yang diobservasi }}{\text { Skor yang diharapkan }} \times 100 \%$

Prosentase Kelayakan $(\%)=\frac{33}{50} \times 100 \%$

Adapun rekapitulasi perhitungan prosentase disajikan dalam grafik gambar 5. berikut ini. 


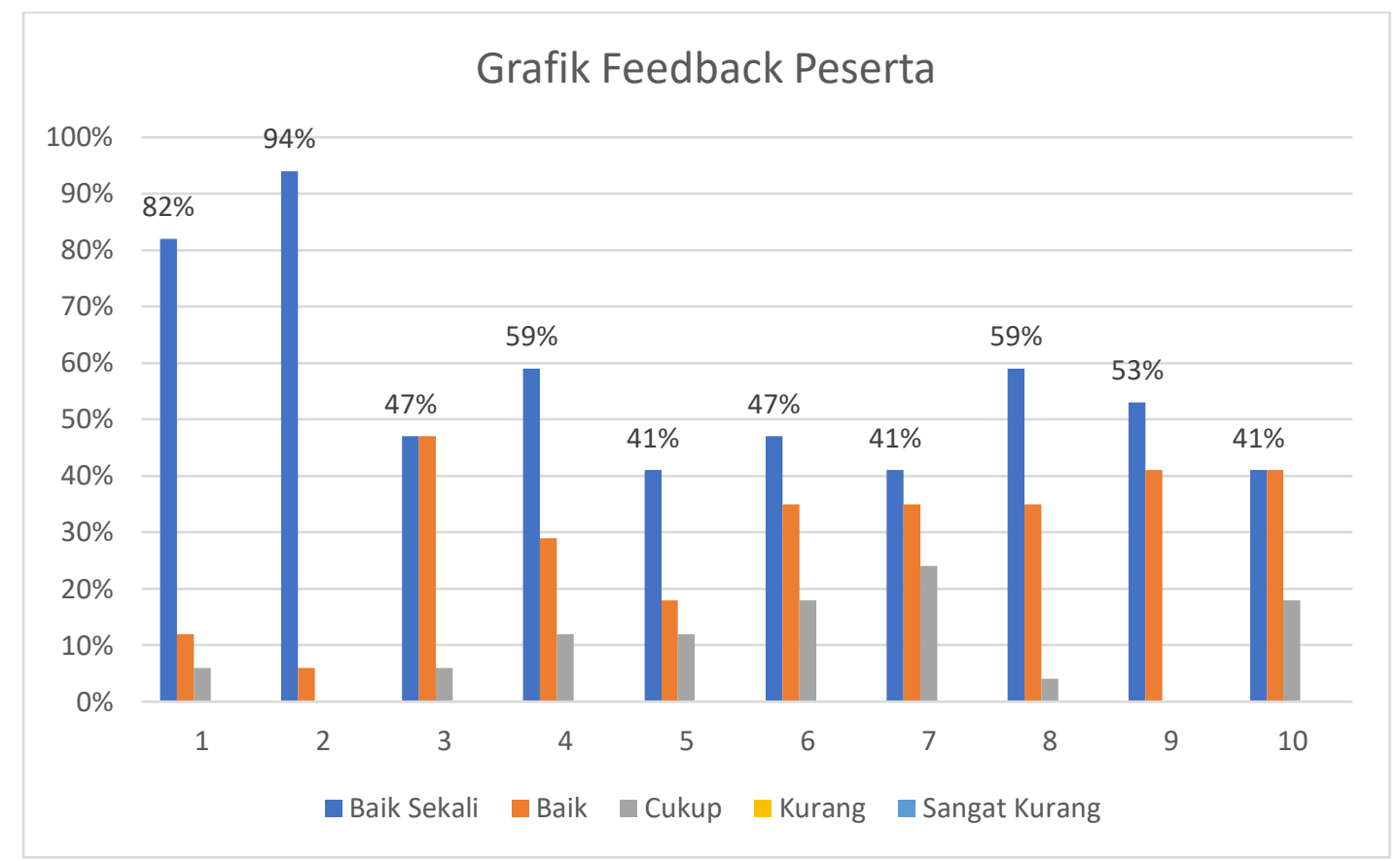

Sumber: Hasil Pelaksanaan (2021)

Gambar 5. Grafik rekap prosentase kelayakan

Pada gambar 1. menjelaskan tetang rekap prosentase kelayakan yang disajikan dalam bentuk grafik, dimana sumbu $x$ menjelaskan tentang kriteria penilaian sedangkan sumbu $y$ menjelaskan presentase. Berdasarkan data diatas dapat disimpulkan bahwa rata-rata respon peserta memberikan umpan balik yang bagus dengan nilai sebesar $82 \%$ untuk materi yang dibawakan oleh narasumber. Peserta memberikan hasil umpan balik sebesar $94 \%$ untuk respon terhadap materi yang disampaikan oleh narasumber

\section{Kesimpulan}

Pelaksanaan PkM Media Pembelajaran menggunakan Canva bagi pendidikan dan tenaga pendidikan PAUD berjalan lancar hal ini dapat dilihat dari hasil feedback yang disampaikan mitra. Adapun output dari hasil kegiatan PkM adalah respon dari peserta terhadap materi yang disampaikan sesuai dengan kebutuhan yaitu ingin menambah pengetahuan yang lebih mengenai media pembelajaran menggunakan canva hal ini dapat terlihat dari hasil feedback pada pertanyaan mengenai kesesuaian materi dengan kebutuhan peserta terdapat 17 peserta $(82 \%)$ menjawab baik sekali dan (12\%) baik. Pertanyaan respon peserta terhadap materi memberikan hasil sebesar (94\%) menjawab baik sekali dan (6\%) menjawab baik. Pertanyaan keterkaitan materi dengan kebutuahn memberikan hasil sebesar (41\%) menjawab baik sekali dan (18)\% menjawab baik. Berdasarkan hasil dari 3 pertanyaan dari 10 pertanyaan yang diberikan dapat ditarik kesimpulan bahwa kegiatan PkM telah menjawab permasalahan yang dihadapi mitra dan menjadi masukan bagi mitra untuk memanfaatkan media pembelajaran dimasa yang akan datang. Adapun saran yang diberikan peserta kegiatan PkM terkait materi yang disampaikan adalah lebih sering dilakukan kegiatan serupa dan memperbanyak lagi materi seperti media 
pembelajaran. Dan saran yang diberikan terkait panitia pelaksana kegiatan adalah "tetap semangat dan sukses terus dalam menyelenggarakan kegiatan selanjutnya".

\section{Ucapan Terima Kasih (Opsional)}

Tim Pengabdian kepada Masyarakat mengucapkan banyak terimakasih kepada Direktorat Jenderal Pendidikan Tinggi, Riset dan Teknologi Kementerian Pendidikan, Kebudayaan, Riset dan Teknologi yang telah memberikan bantuan pembiayaan program penelitian kebijakan merdeka belajar kampus merdeka dan Pengabdian kepada Masyarakat berbasis penelitian ini dan telah mendukung selama berjalannya kegiatan.

\section{Daftar Pustaka}

Adittia, A. (2017). Penggunaan Media Pembelajaran Audio Visual Untuk Meningkatkan Hasil Belajar Ips Pada Siswa Kelas Iv Sd. Mimbar Sekolah Dasar, 4(1), 9-20. https://doi.org/10.23819/mimbar-sd.v4i1.5227

Budiman, H. (2017). Peran Teknologi Informasi Dan Komunikasi Dalam Pendidikan. AlTadzkiyyah: Jurnal Pendidikan Islam, 8(1), 31. https://doi.org/10.24042/atjpi.v8i1.2095

Fitria, V. A., Habibi, A. R., Hakim, L., \& Islamiyah, M. (2021). Pemanfaatan Canva untuk Mendukung Media Pembelajaran Online Siswa Siswi SMK Mahardika Karangploso Malang di Masa Pandemi. Jurnal Pengabdian Masyarakat, 1(2), 75-82. http://jurnal.unmuhjember.ac.id/index.php/Mujtama/article/view/5050

Kusuma, W. A., Noviasari, V., \& Marthasari, G. I. (2016). Analisis Usability dalam User Experience pada Sistem KRS Online UMM menggunakan USE Questionnaire. Jurnal Nasional Teknik Elektro Dan Teknologi Informasi (JNTETI), 5(4), 294-301. https://doi.org/10.22146/jnteti.v5i4.277

Magdalena, \& Astikawati, Y. (2018). Analisis Penggunaan Media Audio Visual Dalam Pelajaran Ekonomi Di Kelas X Smp Karya Sekadau. JURKAMI : Jurnal Pendidikan Ekonomi, 3(1).

Pelangi, G., Syarif, U., \& Jakarta, H. (2020). Pemanfaatan Aplikasi Canva Sebagai Media Pembelajaran Bahasa Dan Sastra Indonesia Jenjang SMA/MA. Jurnal Sasindo UNPAM, 8(2), 79-96. http://www.openjournal.unpam.ac.id/index.php/Sasindo/article/view/8354

Rahmatullah, R., Inanna, I., \& Ampa, A. T. (2020). Media Pembelajaran Audio Visual Berbasis Aplikasi Canva. Jurnal Pendidikan Ekonomi Undiksha, 12(2), 317-327.

Sholeh, M., Rachmawati, R. Y., \& Susanti, E. (2020). Penggunaan Aplikasi Canva Untuk Membuat Konten Gambar Pada Media Sosial Sebagai Upaya Mempromosikan Hasil Produk Ukm. SELAPARANG Jurnal Pengabdian Masyarakat Berkemajuan, 4(1), 430. https://doi.org/10.31764/jpmb.v4i1.2983

Sony Junaedi. (2021). Aplikasi Canva Sebagai Media Pembelajaran Daring Mahasiswa Pada $\begin{array}{llll}\text { Mata Kuliah } & \text { English } & \text { 80-89. }\end{array}$ https://jurnal.polines.ac.id/index.php/bangun_rekaprima/article/view/3000/107647 
Suryana, Sugiyono, Sekaran, U., Lee, S., Stearns, T., \& Geoffrey, G. M. (2013). Metode Penelitian Kuantitatif, Kualitatif, dan R\&D. In International Journal of Management (Edisi 4, Vol. 29, Issue 1). Salemba Empat.

Tedjawati, J. (2011). Peran HIMPAUDI Dalam Pengembangan PAUD. Jurnal Pendidikan Dan Kebudayaan, 17(1), 123. https://doi.org/10.24832/jpnk.v17i1.12 